\title{
Comparative phylogeography of two related plant species with overlapping ranges in Europe, and the potential effects of climate change on their intraspecific genetic diversity
}

\author{
Gemma E Beatty, Jim Provan*
}

\begin{abstract}
Background: The aim of the present study was to use a combined phylogeographic and species distribution modelling approach to compare the glacial histories of two plant species with overlapping distributions, Orthilia secunda (one-sided wintergreen) and Monotropa hypopitys (yellow bird's nest). Phylogeographic analysis was carried out to determine the distribution of genetic variation across the range of each species and to test whether both correspond to the "classic" model of high diversity in the south, with decreasing diversity at higher latitudes, or whether the cold-adapted $O$. secunda might retain more genetic variation in northern populations. In addition, projected species distributions based on a future climate scenario were modelled to assess how changes in the species ranges might impact on total intraspecific diversity in both cases.

Results: Palaeodistribution modelling and phylogeographic analysis using multiple genetic markers (chloroplast trnS-trnG region, nuclear ITS and microsatellites for O. secunda; chloroplast rps2, nuclear ITS and microsatellites for M. hypopitys) indicated that both species persisted throughout the Last Glacial Maximum in southern refugia. For both species, the majority of the genetic diversity was concentrated in these southerly populations, whereas those in recolonized areas generally exhibited lower levels of diversity, particularly in M. hypopitys. Species distribution modelling based on projected future climate indicated substantial changes in the ranges of both species, with a loss of southern and central populations, and a potential northward expansion for the temperate M. hypopitys.

Conclusions: Both Orthilia secunda and Monotropa hypopitys appear to have persisted through the LGM in Europe in southern refugia. The boreal $O$. secunda, however, has retained a larger proportion of its genetic diversity in more northerly populations outside these refugial areas than the temperate M. hypopitys. Given that future species distribution modelling suggests northern range shifts and loss of suitable habitat in the southern parts of the species' current distributions, extinction of genetically diverse rear edge populations could have a significant effect in the rangewide intraspecific diversity of both species, but particularly in M. hypopitys.
\end{abstract}

\section{Background}

Paleoclimatic evidence indicates that the Earth's temperature has been continually changing over time [1-3]. The glacial and interglacial cycles that characterised the Quaternary period (ca. 2.6 MYA - present) have had a significant effect on the distributions of species, particularly in the northern latitudes $[4,5]$. Temperate species

\footnotetext{
* Correspondence: J.Provan@qub.ac.uk

School of Biological Sciences, Queen's University Belfast, 97 Lisburn Road, Belfast BT9 7BL, Northern Ireland
}

were generally confined to low-latitude refugia throughout glacial periods and recolonized from these areas as the climate warmed during interglacials [6,7]. For plant species, however, whose spread is primarily via dispersal of seeds, the capacity to track changes in suitable habitat is limited, particularly for animal-dispersed species [8].

Understanding the past movements of species may help us understand how present and future climate change might affect species' ranges $[9,10]$. Within the last decade, it has become evident that anthropogenically induced climate change is causing shifts in the

\section{C) Biomed Central}


distribution ranges of many species [11-14]. As projections of carbon emissions suggest that this period of global warming will not end soon, these range shifts are likely to continue, but where species lack the migratory capacity to track changes in climate and available habitat, population extinctions may become increasingly frequent, particularly at species' low-latitude range edges [14-17]. Range-edge populations have generally been perceived as being genetically depauperate $[18,19]$, although it has recently been suggested that some rearedge populations may serve as reservoirs of unique genetic variation [20]. The processes of persistence in southern refugia during glacial maxima followed by northward recolonization have led to a pattern of "southern richness versus northern purity" [21-23], where the majority of genetic variation is found in populations that currently occupy previous refugial areas, with a northward decrease in genetic diversity due to progressive founder effects during the recolonization process (but see [24-27]). Consequently, if rear-edge populations are at particular risk of extinction due to the effects of climate change, their loss may have a disproportionally detrimental impact on overall levels of within-species genetic diversity, and such genetic erosion might compromise the long-term evolutionary potential of impacted species [28]. Assuming that species will shift their ranges north in response to global warming, genetically diverse southern edge populations of temperate species may be at the greatest risk of extinction, whereas cold-adapted species that might have persisted in more northerly refugia [24-27] could conceivably retain a larger proportion of their genetic diversity since this variation may not be concentrated in low latitude populations.

The aim of the present study was to use a combined phylogeographic and species distribution modelling approach to compare the glacial histories of two plant species, Orthilia secunda (one-sided wintergreen) and Monotropa hypopitys (yellow bird's nest). Both species belong to the Monotropoideae and have largely overlapping ranges in Europe (Figures $1 \mathrm{~A}$ and $1 \mathrm{~B}$ ), as well as being found in North America, where they both exhibit disjunct east/west distributions. O. secunda is generally found in boreal forests, whereas $M$. hypopitys is usually associated with more temperate tree species and thus a comparison of the two should provide insights into the relative effects of climate change on a temperate species vs. a boreal species. Phylogeographic analysis was carried out to determine the distribution of genetic variation across the range of each species and to test whether both correspond to the "classic" model of high diversity in the south, with decreasing diversity at higher latitudes, or whether the cold-adapted O. secunda might retain more genetic variation in northern populations.
In addition, projected species distributions based on a future climate scenario were modelled to assess how changes in the species ranges might impact on total intraspecific diversity in both cases.

\section{Methods}

\section{Sampling and DNA extraction}

Samples of Orthilia secunda and Monotropa hypopitys were obtained from 35 and 19 locations respectively throughout Europe (Tables 1 and 2). DNA was extracted using the Qiagen DNeasy kit. For O. secunda, 206 individuals were sequenced for the chloroplast trnS$\operatorname{trn} \mathrm{G}$ intergenic spacer, 154 individuals were sequenced for the nuclear internal transcribed spacer (ITS) region, and 218 individuals genotyped for five nuclear microsatellite loci. For M. hypopitys, 100 individuals were sequenced for part of the chloroplast rps 2 gene, 100 individuals were sequenced for the nuclear ITS region, and 111 individuals were genotyped for eight nuclear microsatellite loci.

\section{Species distribution modelling}

Ecological niche modelling (ENM) was carried out to determine suitable climate envelopes for O. secunda and M. hypopitys in Europe for the LGM (ca. 18KYA), and the year 2100 under a future climate scenario using the maximum entropy approach implemented in the MAXENT software package (V3.2.1; [29]). Species occurrence data were downloaded from the Global Biodiversity Information Facility data portal (http://www.gbif.org), totalling 14,221 and 8,829 occurrences for O. secunda and $M$. hypopitys respectively. A principal component analysis (PCA) was carried out on the 19 BIOCLIM variables in the WorldClim data set [30] to remove correlated variables, since these can lead to overfitting of the model. After removing variables that exhibited a strong correlation (Spearman's rank correlation $>0.5$; [31]), three variables (P1 [Annual Mean Temperature], P4 [Temperature Seasonality] and P14 [Precipitation of Driest Period]) were used to generate ENMs at 2.5 minute resolution using MAXENT with the default parameters for convergence threshold $\left(10^{-5}\right)$ and number of iterations (500), and projected onto reconstructed LGM data (Community Climate System Model [CCSM]; Palaeoclimate Modelling Intercomparison Project Phase II: http://pmip2.lsce.ipsl.fr) to identify potential refugial areas. The current climate envelope was also projected onto climate grids corresponding to the same three bioclimatic variables in the year 2100 under the National Centre for Atmospheric Research general circulation model (CCM3 model) that simulates double $\mathrm{CO}_{2}$ emissions [32]. Duplicate records from the same locality were removed to reduce the effects of spatial autocorrelation. Presence thresholds were determined using the 

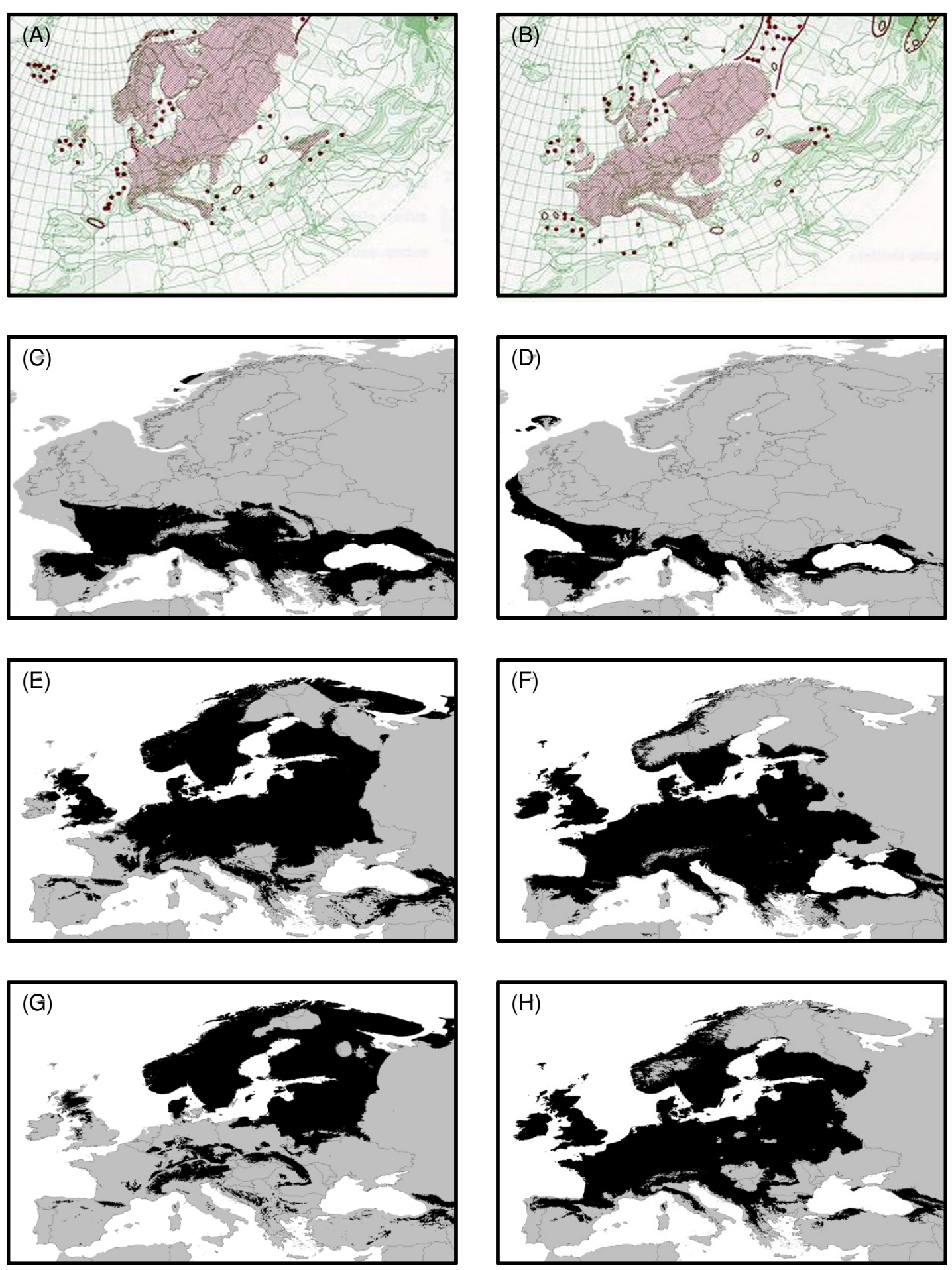

Figure 1 Distributions of $O$. secunda and $M$. hypopitys, and modelled LGM, current and future distributions. (A) Distribution of O. secunda (Source: Naturhistoriska riksmuseet) (B) Distribution of M. hypopitys (Source: Naturhistoriska riksmuseet) (C) Modelled LGM (ca. 18 KYA) distribution of $\mathrm{O}$. secunda (D) Modelled LGM (ca. 18 KYA) distribution of M. hypopitys (E) Modelled current distribution of O. secunda (F) Modelled current distribution of M. hypopitys (G) Modelled future (2100) distribution of O. secunda (D) Modelled future (2100) distribution of M. hypopitys. 
Table 1 Orthilia secunda populations analysed in this study

\begin{tabular}{|c|c|c|c|c|c|c|c|c|}
\hline Country & Location & Code & Lat & Long & $N_{c p}$ & $N_{I T S}$ & $N_{\text {micro }}$ & Collector \\
\hline \multirow[t]{3}{*}{ Austria } & Radmer an der Stube & ATRS & 47.5556 & 14.7861 & 5 & 2 & 5 & Apollonie Mayr \\
\hline & Steiermark & ATS1 & 47.4967 & 14.3522 & 7 & 5 & 8 & Peter Schönswetter \\
\hline & Steiermark & ATS2 & 47.4389 & 14.9233 & 8 & 7 & 8 & Peter Schönswetter \\
\hline Czech Republic & Kosatky & CZKO & 50.3178 & 14.6719 & 7 & 6 & 7 & Petr Kotlik \\
\hline \multirow[t]{3}{*}{ Estonia } & Jõgevamaa & EEJO & 58.6338 & 26.9453 & 7 & 2 & 8 & Teene Talve \\
\hline & Nigula Nature Reserve & EENN & 58.0194 & 24.6825 & 7 & 5 & 8 & M. Reintal \\
\hline & Põlvamaa & EEPO & 58.0956 & 27.0302 & 8 & 4 & 8 & T. Oja \\
\hline \multirow[t]{3}{*}{ France } & Cervieres & FRCE & 44.8667 & 6.7225 & 7 & 5 & 8 & Rolland Douzet \\
\hline & Sauvas & FRSA & 44.6004 & 5.9037 & 5 & 4 & 7 & Arne Saatkamp \\
\hline & Station Alpine Joseph Fourier & FRJF & 45.0360 & 6.4002 & 6 & 5 & 8 & Rolland Douzet \\
\hline \multirow[t]{2}{*}{ Ireland } & Correl Glen & IECG & 54.4372 & -7.8744 & 4 & 4 & 4 & Gemma Beatty \\
\hline & Cranny Burn & $\mathrm{IECB}$ & 54.9114 & -6.0409 & 4 & 4 & 4 & Gemma Beatty \\
\hline Italy & Valle D'Aosta & ITVA & 45.7125 & 7.1639 & 6 & 5 & 6 & Nationaal Herbarium Nederland \\
\hline \multirow[t]{2}{*}{ Montenegro } & Durmitor Mountains & MEDM & 43.1611 & 19.2028 & 8 & 7 & 8 & Anna \& Michal Ronikier \\
\hline & Komovi Massif & MEKM & 42.6947 & 19.6672 & 5 & 4 & 5 & Anna \& Michal Ronikier \\
\hline \multirow[t]{4}{*}{ Norway } & Buskerud & NOBU & 60.1208 & 10.3833 & 8 & 6 & 8 & Andreas Tribsch \\
\hline & Oslo & NOOS & 59.9939 & 10.7064 & 8 & 6 & 8 & Andreas Tribsch \\
\hline & Selvikstaken & NOSE & 58.8625 & 6.0750 & 4 & 4 & 4 & Andreas Tribsch \\
\hline & Troms Fylke & NOTF & 68.9500 & 19.7500 & 4 & 4 & 5 & W. Paul \\
\hline \multirow[t]{3}{*}{ Poland } & Bialystok & PLBI & 53.1167 & 23.1167 & 8 & 4 & 8 & Ada Wroblewska \\
\hline & Kielce & PLKI & 50.8400 & 20.5800 & 5 & 5 & 5 & W. Paul \\
\hline & Pomorze Zachodnie & PLPZ & 54.0047 & 19.9983 & 7 & 6 & 8 & Joanna Julia \& Lech Galosz \\
\hline \multirow[t]{2}{*}{ Scotland } & Glen Glass & SCGG & 57.6816 & -4.4226 & 4 & 4 & 4 & Peter McEvoy \\
\hline & Glen Mhor & SCGM & 56.8844 & -3.6315 & 4 & 4 & 4 & Peter McEvoy \\
\hline \multirow[t]{4}{*}{ Slovakia } & Muranska Planina & SKMP & 48.7825 & 19.9600 & 8 & 5 & 8 & Anna \& Michal Ronikier \\
\hline & Nizke Tatry & SKNT & 48.9983 & 19.5875 & 8 & 5 & 8 & Anna \& Michal Ronikier \\
\hline & Slovensky Raj & SKSR & 48.9305 & 20.2897 & 2 & 2 & 2 & Anna \& Michal Ronikier \\
\hline & Zapadne Tatry & SKZT & 49.1453 & 19.7850 & 7 & 6 & 7 & Anna \& Michal Ronikier \\
\hline Slovenia & Kaminske Alpe & SIKA & 46.3922 & 14.6000 & 8 & 6 & 8 & Peter Schönswetter \\
\hline \multirow[t]{3}{*}{ Sweden } & Flurkmark & SEFL & 64.1273 & 20.1322 & 8 & 7 & 8 & Stefan Ericsson \\
\hline & Lomselenas & SELO & 65.1441 & 17.3139 & 8 & 6 & 8 & Stefan Ericsson \\
\hline & Ranas & SERA & 59.8128 & 18.2883 & 5 & 1 & 8 & Arne Anderberg \\
\hline \multirow[t]{3}{*}{ Switzerland } & Chasseron & $\mathrm{CHCH}$ & 46.8287 & 6.5508 & 6 & 6 & 6 & Philippe Druart \\
\hline & Valais & CHVA & 46.0000 & 7.6833 & 5 & 5 & 5 & Nationaal Herbarium Nederland \\
\hline & & & & & 206 & 154 & 218 & \\
\hline
\end{tabular}

sensitivity-specificity sum maximisation approach [33] and the performance of the models were tested using $25 \%$ of the occurrence data points to determine the area under the receiver operating characteristic (ROC) curve (AUC).

\section{Molecular genetic analyses - 0 . secunda}

206 individuals were sequenced for the chloroplast trnStrn $\mathrm{G}$ intergenic spacer. A product was amplified using the $O$. secunda-specific primers and reaction conditions described in [34]. $5 \mu \mathrm{l}$ PCR product were resolved on $1.5 \%$ agarose gels and visualised by ethidium bromide staining, and the remaining $15 \mu \mathrm{l}$ sequenced in both directions using the BigDye sequencing kit (V3.1; Applied Biosystems) and run on an AB 3730XL DNA analyser.
154 individuals were sequenced for a section of the nuclear ITS region. Primers were designed from GenBank sequence accession number AF133747: OS-ITS-F 5'-TGTTTGTACACTTGGGGAAGC-3' and OS-ITS-R 5'-TCGCGGTCAATGTACCGTAG-3'. PCR and sequencing were carried out as described in [34], except that an annealing temperature of $55^{\circ} \mathrm{C}$ was used for the PCR.

218 individuals were genotyped for five O. secunda microsatellite loci previously described in [35]. Forward primers were modified by the addition of a 19 bp M13 tail (5'-CACGACGTTGTAAAACGAC-3') and reverse primers were modified by the addition of a 7 bp tail (5'-GTGTCTT-3'). PCR was carried out in a total volume of $10 \mu \mathrm{l}$ containing $100 \mathrm{ng}$ genomic DNA, 10 
Table 2 Monotropa hypopitys populations analysed in this study

\begin{tabular}{|c|c|c|c|c|c|c|c|c|}
\hline Country & Location & Code & Lat & Long & $N_{c p}$ & $N_{\text {ITS }}$ & $N_{\text {micro }}$ & Collector \\
\hline Austria & Karnten & ATKA & 46.5228 & 13.9539 & 2 & 2 & 2 & Peter Schönswetter \\
\hline Czech Republic & Polom & CZPO & 49.7892 & 15.7595 & 1 & 1 & 1 & Jakub Tiesetel \\
\hline England & Peasmarsh & ENPE & 50.9667 & -0.6667 & 6 & 6 & 8 & Jonathan Simmons \\
\hline \multirow[t]{2}{*}{ Estonia } & Jõgevamaa & EEJO & 58.6338 & 26.9453 & 6 & 6 & 8 & Teene Talve \\
\hline & Põlvamaa & EEPO & 58.0956 & 27.0302 & 7 & 8 & 8 & T. Ota \\
\hline \multirow[t]{2}{*}{ Ireland } & Ely Lodge & IEEL & 54.4567 & -7.9002 & 8 & 7 & 8 & Gemma Beatty \\
\hline & Straidkilly & IEST & 54.9914 & -6.0409 & 8 & 7 & 8 & Gemma Beatty \\
\hline \multirow[t]{3}{*}{ Poland } & Czarne Lake & PLCL & 53.4667 & 20.6000 & 8 & 7 & 8 & Ada Wroblewska \\
\hline & Lake Golun & PLLG & 54.0047 & 17.9983 & 8 & 8 & 8 & Ada Wroblewska \\
\hline & Knyszyn & PLKN & 53.3333 & 22.9167 & 8 & 8 & 8 & Joanna Julia \& Lech Galosz \\
\hline \multirow[t]{2}{*}{ Romania } & Retezat Mountains & RORM & 45.3097 & 22.9678 & 8 & 8 & 8 & Anna \& Michal Ronikier \\
\hline & & ROVG & 46.2070 & 25.5400 & 4 & 4 & 6 & Anna Maria Csergo \\
\hline \multirow[t]{2}{*}{ Slovakia } & Muranska Planina & SKMP & 48.7825 & 19.9600 & 2 & 2 & 2 & Anna \& Michal Ronikier \\
\hline & Nizke Tatry & SKNT & 48.9983 & 19.5875 & 4 & 4 & 6 & Anna \& Michal Ronikier \\
\hline \multirow[t]{2}{*}{ Slovenia } & Dolenjska & SIDO & 45.9236 & 15.0958 & 2 & 3 & 3 & Peter Schönswetter \\
\hline & Soca Valley & SISV & 46.3450 & 13.6800 & 8 & 8 & 8 & Peter Schönswetter \\
\hline Sweden & Ranas & SERA & 59.8128 & 18.2883 & 3 & 4 & 4 & Arne Anderberg \\
\hline \multirow[t]{2}{*}{ Switzerland } & Chasseron & $\mathrm{CHCH}$ & 46.8287 & 6.5508 & 5 & 5 & 5 & Philippe Druart \\
\hline & & & & & 100 & 100 & 111 & \\
\hline
\end{tabular}

pmol of dye-labelled M13 primer (6-FAM or HEX), 1 pmol of tailed forward primer, 10 pmol reverse primer, $1 \times$ PCR reaction buffer, $200 \mu \mathrm{M}$ each dNTP, $2.5 \mathrm{mM}$ $\mathrm{MgCl}_{2}$ and $0.25 \mathrm{U}$ GoTaq Flexi DNA polymerase (Promega). PCR was carried out on a MWG Primus thermal cycler using the conditions described in [35] and genotyping was carried out on an AB3730xl capillary genotyping system. Allele sizes were scored in GENEMAPPER V4.1 using ROX-500 size standards and were checked by comparison with previously sized control samples.

\section{Molecular genetic analyses - M. hypopitys}

100 individuals were sequenced for a section of the chloroplast rps 2 gene. Primers were designed from GenBank sequence accession number AF351956 (Bidartondo and Bruns 2001): MH-rps2-F 5'-TTCGCCGATTTAGTATCACG-3' and MH-rps2-R 5'-GGGATTCCCAAAGTAATACATTCTA-3'. PCR and sequencing were carried out as described in [34].

100 individuals were sequenced for a section of the nuclear ITS region. Primers were designed from GenBank sequence accession number AF384126 [36]: MHITS-F 5'-GGTTGGCCTACCCTTTATTTT-3' and MHITS-R 5'-GAAGTAATCCAATCATAACACTGACA-3'. $\mathrm{PCR}$ and sequencing were carried out as described in [34], except that an annealing temperature of $55^{\circ} \mathrm{C}$ was used.

111 individuals were genotyped for five $M$. hypopitys microsatellite loci previously described in [37] Mono02, Mono15, Mono20, Mono21 and Mono22.
Three additional loci developed using the ISSR-cloning technique outlined in [38] were also used (Table 2). Forward primers were modified by the addition of a $19 \mathrm{bp}$ M13 tail (5'-CACGACGTTGTAAAACGAC-3') and reverse primers were modified by the addition of a $7 \mathrm{bp}$ tail (5'-GTGTCTT-3'). PCR was carried out in a total volume of $10 \mu \mathrm{l}$ containing $100 \mathrm{ng}$ genomic DNA, 10 pmol of dye-labelled M13 primer (6-FAM or HEX), 1 pmol of tailed forward primer, 10 pmol reverse primer, $1 \times$ PCR reaction buffer, $200 \mu \mathrm{M}$ each dNTP, $2.5 \mathrm{mM} \mathrm{MgCl}_{2}$ and $0.25 \mathrm{U}$ GoTaq Flexi DNA polymerase (Promega). PCR was carried out on a MWG Primus thermal cycler using the conditions described in [39] and genotyping was carried out on an AB3730xl capillary genotyping system. Allele sizes were scored in GENEMAPPER V4.1 (Applied Biosystems) using ROX500 size standards and were checked by comparison with previously sized control samples.

\section{Data analysis}

Alignments were constructed using BIOEDIT (V7.0.9.0) [40] for the O. secunda chloroplast trnS-trnG intergenic spacer and nuclear ITS, and for the M. hypopitys chloroplast rps 2 and nuclear ITS. Length variation at any mononucleotide repeat regions was removed, since the bidirectional mutation model operating at such regions can give rise to homoplasy [41]. The alignments were used to construct statistical parsimony networks using the TCS software package (V1.2.1) [42]. Where reticulations were present in the networks, these were broken following the rules described in [43]. 
Tests for linkage disequilibrium between pairs of microsatellite loci in each population were carried out in the program FSTAT [44]. Levels of genetic diversity were calculated for populations with a sample size of $N \geq 4$. Gene diversity $(H)$ based on haplotype frequencies for the O. secunda chloroplast trnS-trnG region and nuclear ITS, and the M. hypopitys chloroplast rps 2 and nuclear ITS, and observed and expected heterozygosity $\left(H_{O}\right.$ and $H_{E}$ ) based on nuclear microsatellite allele frequencies were calculated using the ARLEQUIN software package (V3.01) [45]. Population structuring based on the microsatellite data was determined using the STRUCTURE software package (V 2.2) [46]. Five independent runs were carried out for all values of $K$, the number of clusters, between 2 and 20. The program was run each time using 50,000 burn-in iterations followed by 500,000 Markov Chain Monte Carlo iterations, and the most likely value of $K$ was determined using the $\Delta K$ statistic [47].

\section{Results}

\section{Species distribution modelling}

For all models, the area under the receiver operating curve (AUC) statistic was consistently higher than 0.95 , indicating good performance.

Distribution modelling for O. secunda and M. hypopitys at the LGM indicated extensive areas of suitable habitat for both species in southern Europe (Figures 1C and 1D). For O. secunda, two of the French populations (FRSA and FRCE), one of the Swiss populations (CHVA) and the two populations from Montenegro lay within the suitable climate envelope indicated by the ENM. None of the $M$. hypopitys populations studied lay within the suitable climate envelope indicated by the ENM.

The future distribution model indicated an extensive loss of suitable habitat for $O$. secunda relative to the modelled current climate envelope (Figure 1E), particularly in northern central Europe (Figure 1G). The majority of the suitable remaining habitat in southern Europe would be largely restricted to the mountainous regions of the Pyrenees, the Alps, the Carpathians and the Dinaric Alps. For $M$. hypopitys, the model indicated a general northward shift in the species' distribution, with a loss of suitable habitat in southeastern Europe but an increase in northern Europe, particularly in Scandinavia (Figures $1 \mathrm{~F}$ and $1 \mathrm{H}$ ).

\section{O. secunda phylogeography}

Removal of length polymorphism at three mononucleotide repeat regions from the chloroplast $\operatorname{trnS}$-trn $\mathrm{G}$ alignment resulted in an overall alignment length of $495 \mathrm{bp}$ and seven distinct haplotypes (Table 3; Figure 2; GenBank sequence accession numbers HQ864688-
Table 3 Diversity statistics for 0 . secunda populations

\begin{tabular}{|c|c|c|c|c|c|c|c|c|c|c|c|c|c|c|}
\hline \multirow[t]{2}{*}{ Country } & \multirow[t]{2}{*}{ Code } & \multirow[t]{2}{*}{$H_{E}$} & \multicolumn{7}{|c|}{ cpDNA haplotype } & \multicolumn{5}{|c|}{ ITS haplotype } \\
\hline & & & 1 & 2 & 3 & 4 & 5 & 6 & 7 & 1 & 2 & 3 & & 5 \\
\hline \multirow[t]{3}{*}{ Austria } & ATRS & 0.729 & - & 5 & - & - & - & - & - & 5 & - & - & - & - \\
\hline & ATS1 & 0.529 & - & 6 & - & 1 & - & - & - & 7 & - & - & & - \\
\hline & ATS2 & 0.629 & - & 5 & 2 & - & 1 & 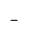 & - & 8 & - & - & & - \\
\hline Czech Republic & CZKO & 0.736 & 7 & - & - & 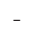 & - & - & - & 4 & 2 & - & & - \\
\hline \multirow[t]{3}{*}{ Estonia } & EEJO & 0.768 & 1 & - & 6 & - & - & - & - & 1 & 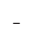 & - & - & - \\
\hline & EENN & 0.752 & - & 1 & 6 & - & - & - & - & - & - & 5 & & - \\
\hline & EEPO & 0.797 & - & 7 & 1 & - & - & - & - & 1 & - & - & - & - \\
\hline \multirow[t]{3}{*}{ France } & FRCE & 0.737 & 4 & 2 & 1 & - & - & - & - & 3 & 1 & - & - & 1 \\
\hline & FRSA & 0.811 & 5 & - & - & - & - & - & - & 2 & - & - & 2 & - \\
\hline & FRJF & 0.765 & 6 & - & - & - & - & - & - & 5 & - & - & - & - \\
\hline \multirow[t]{2}{*}{ Ireland } & IECG & 0.400 & - & 4 & - & - & - & - & - & 4 & - & - & - & _ \\
\hline & $\mathrm{IECB}$ & 0.643 & - & 4 & - & - & - & - & - & 4 & - & - & - & - \\
\hline Italy & ITVA & 0.637 & 6 & - & - & - & - & - & - & 5 & - & - & - & - \\
\hline \multirow[t]{2}{*}{ Montenegro } & MEDM & 0.757 & 8 & - & - & - & - & - & - & 7 & - & - & - & - \\
\hline & MEKM & 0.807 & 4 & - & 1 & - & - & - & - & 4 & - & - & - & - \\
\hline \multirow[t]{4}{*}{ Norway } & NOBU & 0.727 & 3 & 4 & - & - & - & 1 & - & 6 & - & - & - & - \\
\hline & NOOS & 0.839 & - & 4 & 4 & - & - & - & - & 5 & - & - & 1 & - \\
\hline & NOSE & 0.839 & - & - & 4 & - & - & - & - & 4 & - & - & - & - \\
\hline & NOTF & 0.409 & - & 3 & 1 & - & - & - & - & 4 & - & - & - & - \\
\hline \multirow[t]{3}{*}{ Poland } & PLBI & 0.493 & 8 & - & - & - & - & - & - & 4 & - & - & - & - \\
\hline & PLKI & 0.582 & 5 & - & - & - & - & - & - & 5 & - & - & - & - \\
\hline & PLPZ & 0.770 & 7 & - & - & - & - & - & - & 6 & - & - & - & - \\
\hline \multirow[t]{2}{*}{ Scotland } & SCGG & 0.429 & - & - & 4 & - & - & - & - & 4 & - & - & - & - \\
\hline & SCGM & 0.529 & - & 4 & - & - & - & - & - & 4 & - & - & - & - \\
\hline \multirow[t]{4}{*}{ Slovakia } & SKMP & 0.807 & 4 & 2 & 2 & - & - & - & - & 4 & 1 & - & - & - \\
\hline & SKNT & 0.772 & 7 & - & - & - & - & - & 1 & 5 & - & - & - & - \\
\hline & SKSR & NC & 2 & - & - & - & - & - & - & 2 & - & - & - & - \\
\hline & SKZT & 0.763 & 7 & - & - & - & - & - & - & 6 & - & - & - & - \\
\hline Slovenia & SIKA & 0.755 & 8 & - & - & - & - & - & - & 4 & 2 & - & - & - \\
\hline \multirow[t]{3}{*}{ Sweden } & SEFL & 0.517 & - & 4 & 3 & 1 & - & - & - & 7 & - & - & - & - \\
\hline & SELO & 0.435 & - & 1 & 7 & - & - & 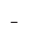 & - & 6 & - & - & - & - \\
\hline & SERA & 0.735 & - & 3 & 2 & . & - & - & - & 1 & - & - & - & - \\
\hline \multirow[t]{2}{*}{ Switzerland } & $\mathrm{CHCH}$ & 0.673 & 6 & _ & - & - & - & - & - & 6 & - & - & - & - \\
\hline & CHVA & 0.755 & 5 & - & - & - & - & - & - & 5 & - & - & - & \\
\hline
\end{tabular}

HQ864694). Three of these (Haplotypes 5, 6 and 7) were unique to a single individual. The three most common haplotypes exhibited a general north-south split, with the Haplotype 2 (yellow) found predominantly in southern populations whilst northern populations contained primarily the two blue haplotypes (Haplotypes 1 and 3). Two populations contained all three of these haplotypes: the FRCE population (France) and the SKMP population (Slovakia). The fourth non-unique haplotype, Haplotype 4 (green), was found in a single individual in both the ATST1 (Austria) and the SELO (Sweden) populations.

The 475 bp nuclear ITS alignment contained five distinct haplotypes (Table 3; Figure 3; GenBank sequence accession numbers HQ864695-HQ864699). The most 


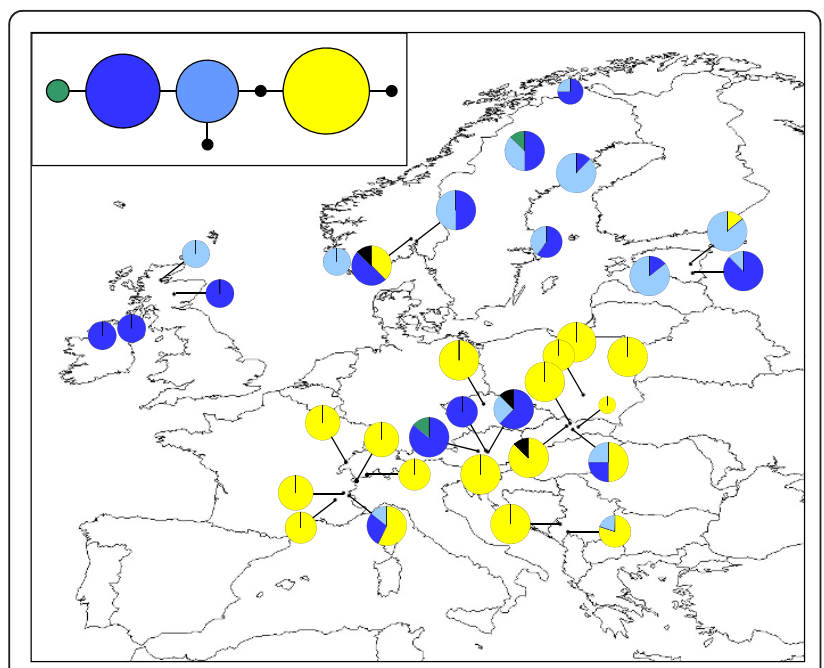

Figure 2 Geographical distribution of $O$. secunda chloroplast trnS-trnG haplotypes. Pie chart sizes are approximately proportional to sample size, with the smallest circles representing $N=1$ and the largest representing $N=8$. Inset shows the phylogenetic relationships between the seven haplotypes. Small black circles represent unique haplotypes i.e. those found in a single individual. The population of origin of each unique haplotype is indicated.

common haplotype, Haplotype 1 (red), was found in all populations with the exception of the EENN population (Estonia). Only six populations exhibited any withinpopulation variation (FRCE, FRSA [both France], SIKA [Slovenia], SKMP [Slovakia], CZKO [Czech Republic] and NOOS [Norway]) and only the FRCE population

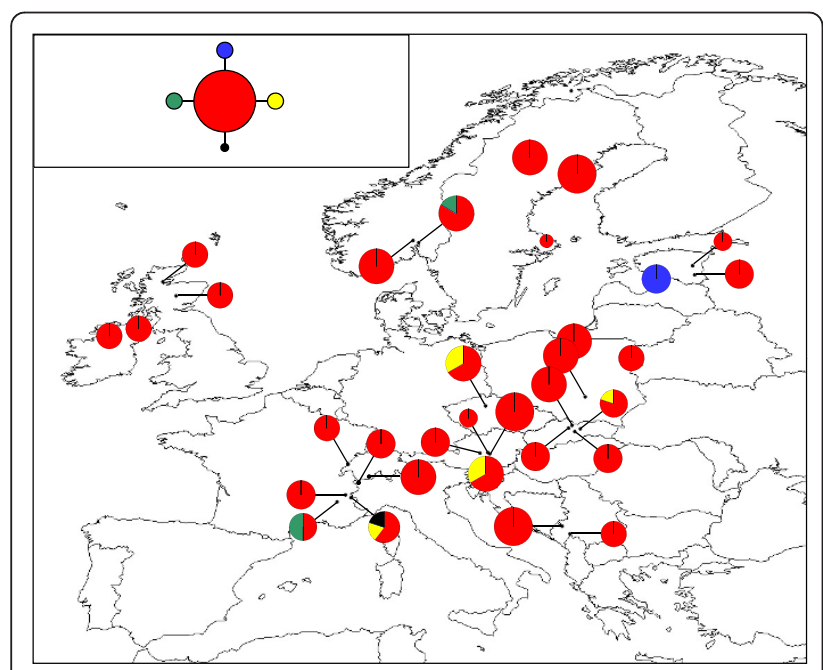

Figure 3 Geographical distribution of $O$. secunda nuclear ITS haplotypes. Pie chart sizes are approximately proportional to sample size, with the smallest circles representing $N=1$ and the largest representing $N=8$. Inset shows the phylogenetic relationships between the five haplotypes. contained more than two haplotypes. The EENN population was fixed for Haplotype 3 (blue), which was not found elsewhere.

No significant linkage disequilibrium was detected between pairs of microsatellite loci after sequential Bonferroni correction. Between 16 and 30 alleles were detected at the five loci studied $($ mean $=20.20)$ and levels of expected heterozygosity $\left(H_{E}\right)$ calculated for populations with a sample size of $N \geq 4$ ranged from 0.400 (IECG [Ireland]) to 0.839 (NOOS and NOSE [both Norway]), with a mean value of 0.677 (Table 3; Figure 4). The STRUCTURE analysis of the microsatellite data indicated that the most likely number of genetic clusters was $K=2$ (Figure 5).

\section{M. hypopitys phylogeography}

The 320 bp chloroplast rps 2 alignment contained seven distinct haplotypes (Table 4; Figure 6; GenBank sequence accession numbers HQ864700-HQ864706). The two most common haplotypes, Haplotypes 1 and 2 (depicted in blue and yellow), exhibited a largely eastwest split. Only four populations exhibited any withinpopulation variation (ATKA [Austria], SIDO [Slovenia], RORM and ROVG [both Romania]) and of these, only the RORM population contained more than two haplotypes.

The 287 bp nuclear ITS alignment contained three distinct haplotypes (Table 4; Figure 7; GenBank sequence accession numbers HQ864707-HQ865709). The distribution of these haplotypes was broadly congruent with that of the chloroplast rps 2 haplotypes. Only the CHCH (Switzerland), SIDO (Slovenia), SKNT (Slovakia) and ROVG (Romania) populations exhibited

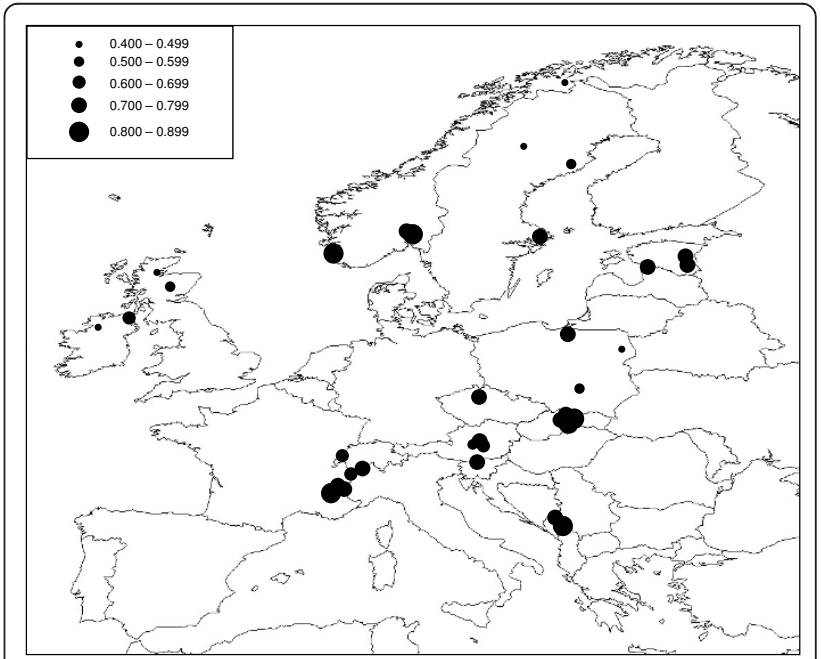

Figure 4 Expected heterozygosity $\left(H_{E}\right)$ in 0 . secunda populations based on five nuclear microsatellite loci. Circle sizes are indicative of level of $H_{E}$ (see inset). 


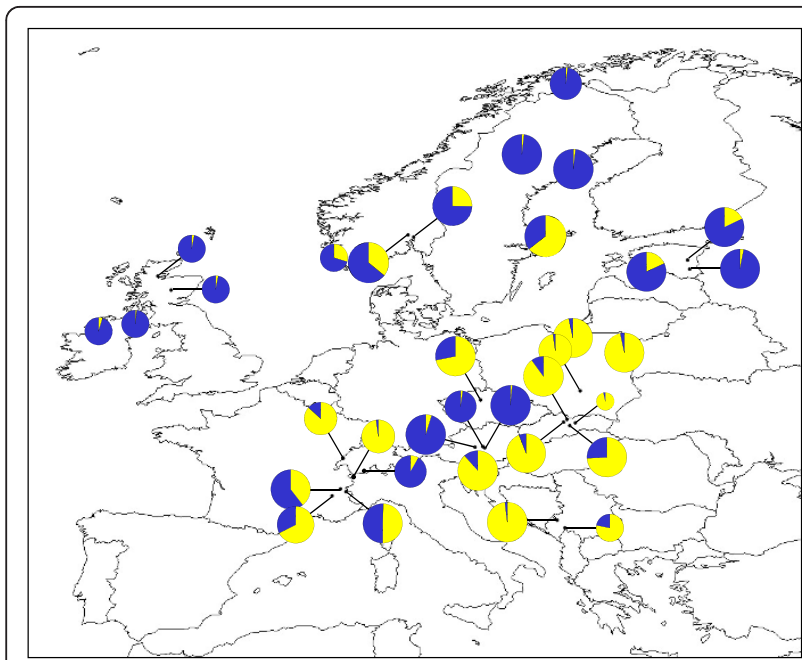

Figure 5 Assignment of $O$. secunda populations to $K=2$ clusters based on STRUCTURE analysis of the nuclear microsatellite data.

any within-population variation, with all three haplotypes being found in the SIDO population.

No significant linkage disequilibrium was detected between pairs of microsatellite loci after sequential Bonferroni correction. Between 10 and 22 alleles were detected at the eight loci studied $($ mean $=15.125)$ and levels of expected heterozygosity $\left(H_{E}\right)$ calculated for populations with a sample size of $N \geq 4$ ranged from 0.370 (IEST [Ireland]) to 0.750 ( $\mathrm{CHCH}$ [Switzerland]), with a mean value of 0.629 (Table 4; Figure 8). The

Table 4 Diversity statistics for $M$. hypopitys populations

\begin{tabular}{|c|c|c|c|c|c|c|c|c|c|c|c|c|}
\hline \multirow[t]{2}{*}{ Country } & \multirow[t]{2}{*}{ Code } & \multirow[t]{2}{*}{$H_{E}$} & \multicolumn{7}{|c|}{ cpDNA haplotype } & \multicolumn{3}{|c|}{ ITS haplotype } \\
\hline & & & 1 & 2 & 3 & 4 & 5 & 6 & 7 & 1 & 2 & 3 \\
\hline Austria & ATKA & NC & 1 & - & 1 & - & - & - & & - & 2 & - \\
\hline Czech Republic & CZPO & NC & 1 & - & - & - & - & - & - & 1 & - & - \\
\hline England & ENPE & 0.624 & - & 6 & - & - & - & - & - & 6 & - & - \\
\hline \multirow[t]{2}{*}{ Estonia } & EEJO & 0.690 & - & 6 & - & - & - & - & & - & 6 & - \\
\hline & EEPO & 0.573 & 7 & - & - & - & - & - & 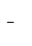 & - & 8 & - \\
\hline \multirow[t]{2}{*}{ Ireland } & IEEL & 0.500 & 8 & - & - & - & - & - & - & 7 & - & - \\
\hline & IEST & 0.370 & 8 & - & - & - & - & - & - & 7 & - & - \\
\hline \multirow[t]{3}{*}{ Poland } & PLCL & 0.516 & - & - & 8 & - & - & - & - & 7 & - & - \\
\hline & PLLG & 0.716 & - & 8 & - & - & - & - & - & - & 8 & - \\
\hline & PLKN & 0.740 & - & 8 & - & - & - & - & - & - & 8 & - \\
\hline \multirow[t]{2}{*}{ Romania } & RORM & 0.731 & - & 4 & - & 1 & 1 & 1 & 1 & - & 8 & - \\
\hline & ROVG & 0.710 & 3 & - & - & 1 & - & - & - & 3 & 1 & - \\
\hline \multirow[t]{2}{*}{ Slovakia } & SKMP & NC & 2 & - & - & - & - & - & - & 2 & - & - \\
\hline & SKNT & 0.682 & 4 & - & - & - & - & - & - & 3 & 1 & - \\
\hline \multirow[t]{2}{*}{ Slovenia } & SIDO & NC & - & - & 1 & 1 & - & - & - & 1 & 1 & 1 \\
\hline & SISV & 0.530 & 8 & - & - & - & - & - & ${ }^{-}$ & 8 & - & - \\
\hline Sweden & SERA & 0.674 & - & 3 & - & - & - & - & 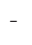 & 4 & - & - \\
\hline Switzerland & $\mathrm{CHCH}$ & 0.750 & 5 & - & - & - & - & - & - & 4 & - & 1 \\
\hline
\end{tabular}

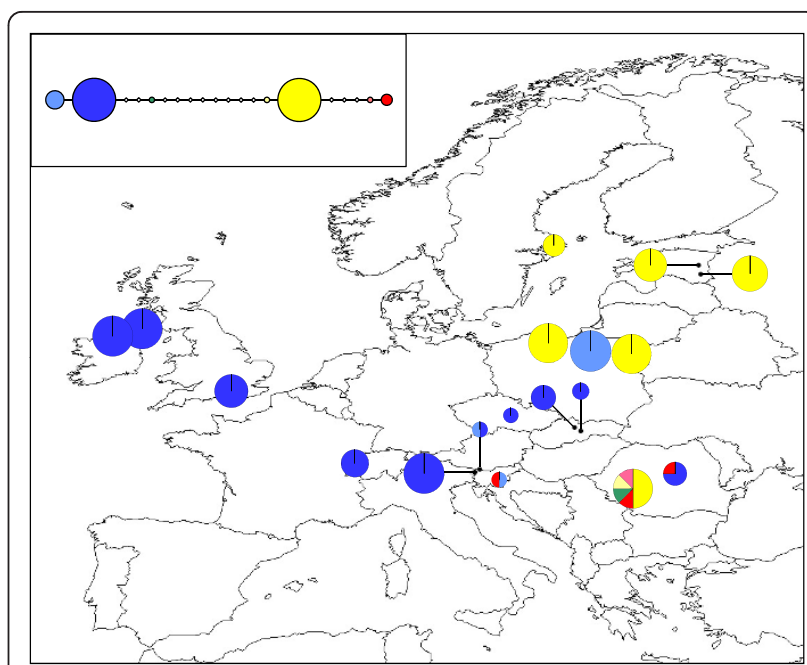

Figure 6 Geographical distribution of $M$. hypopitys chloroplast rps2 haplotypes. Pie chart sizes are approximately proportional to sample size, with the smallest circles representing $N=1$ and the largest representing $N=8$. Inset shows the phylogenetic relationships between the eight haplotypes. Open diamonds represent missing haplotypes.

STRUCTURE analysis of the microsatellite data indicated that the most likely number of genetic clusters was $K=2$ (Figure 9).

\section{Discussion}

It is now apparent that phylogeographic inferences based on a single, non-recombining marker can be misleading [48,49]. Consequently, phylogeographic studies

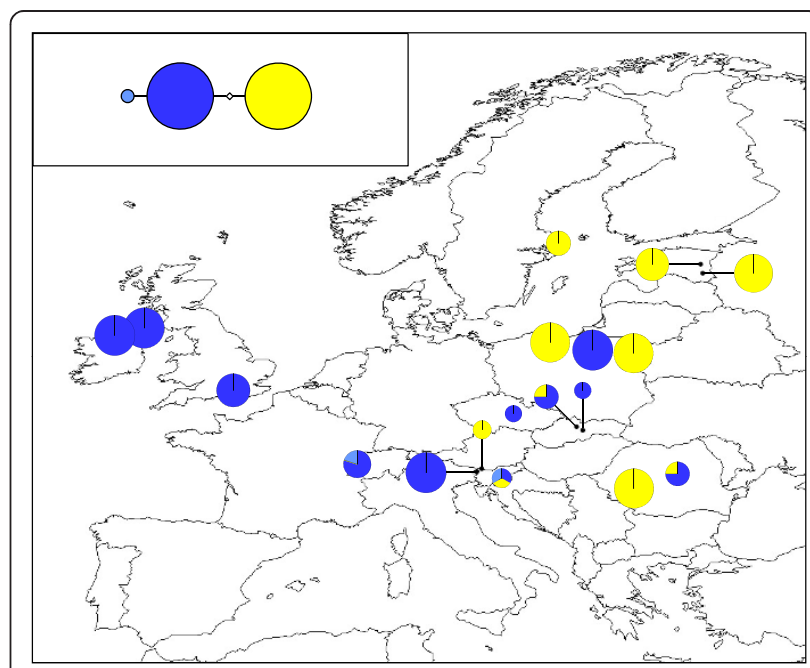

Figure 7 Geographical distribution of $M$. hypopitys nuclear ITS haplotypes. Pie chart sizes are approximately proportional to sample size, with the smallest circles representing $N=1$ and the largest representing $N=8$. Inset shows the phylogenetic relationships between the three haplotypes. Open diamonds represent missing haplotypes. 


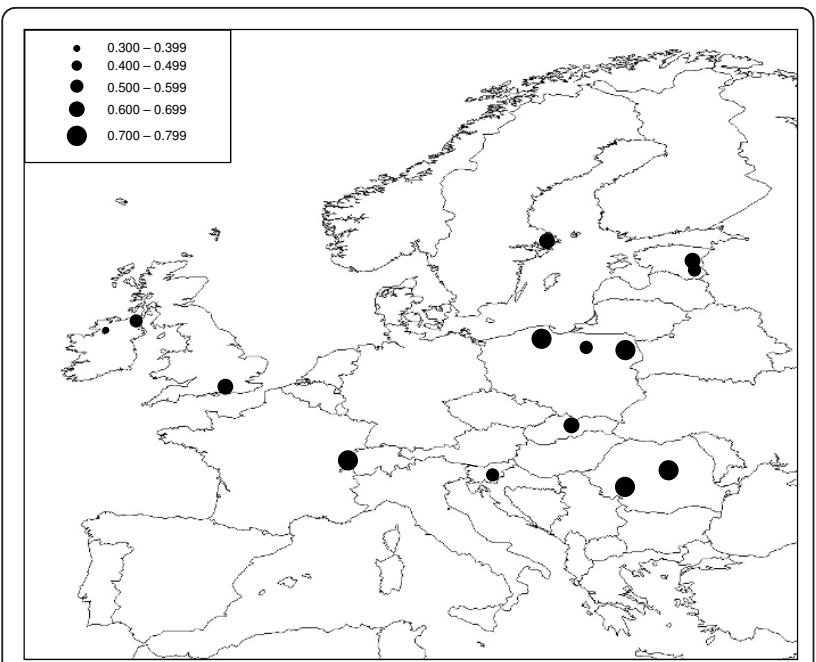

Figure 8 Expected heterozygosity $\left(H_{E}\right)$ in $M$. hypopitys populations based on five nuclear microsatellite loci. Circle sizes are indicative of level of $H_{E}$ (see inset).

are increasingly using multiple genetic markers and/or palaeodistribution modelling to draw more reliable inferences on population history. The results of the paleodistribution modelling and the patterns of genetic variation revealed by the phylogeographic analyses suggest that both Orthilia secunda and Monotropa hypopitys persisted throughout the LGM in Europe in southern refugia. Although both species generally exhibited a "southern richness vs. northern purity" distribution of genetic variation [21], this was more pronounced in the temperate $M$. hypopitys, where the only populations that displayed any within-population genetic variation for both the chloroplast rps 2 and nuclear ITS

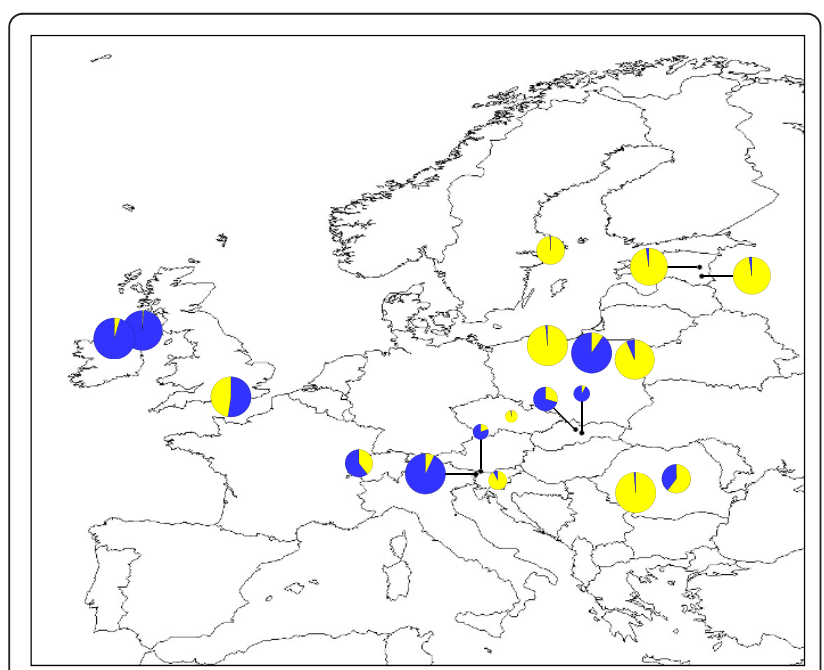

Figure 9 Assignment of $M$. hypopitys populations to $K=2$ clusters based on STRUCTURE analysis of the nuclear microsatellite data. regions were located closest to the modelled refugial areas. Northern populations of O. secunda were more diverse, but the signatures of refugial areas i.e. high diversity coupled with unique haplotypes [27] were restricted to southern populations.

Based on the weight of evidence across modelling and the different markers used, our findings indicate a possible refugial area for O. secunda in Europe located in the vicinity of the French Alps. A second area of high diversity and endemic haplotypes included the Austrian Alps and Slovakia, but these populations lie outside the suitable climate envelope indicated by the palaeodistribution model. Nevertheless, although the precise locations of putative refugia are difficult to identify accurately, it is clear that the majority of genetic diversity is contained in southern populations. The occurrence of a fixed endemic ITS haplotype in one of the Estonian populations (EENN) more likely represents a relatively recent mutation that has become fixed through genetic drift, rather than indicating an extreme northern refugium. For $M$. hypopitys, the modelling and genetic data both indicated a likely refugial area in southeastern Europe. The identification of two genetic clusters with a broadly northern/eastern vs. southern/western geographical distribution for both species based on microsatellite data could indicate isolation in separate refugia followed by differential recolonization after the retreat of the ice [24].

Many studies have used modelling approaches to determine the effects of present and future climate change on the distribution ranges of plant species (e.g. [50-52]). We can extend this approach to investigate the potential effects of such distribution changes on intraspecific genetic diversity. The future modelled distributions of both O. secunda and $M$. hypopitys indicate substantial changes in the ranges of both species. For $M$. hypopitys in particular, these changes could have a profound impact on the genetic diversity of the species in Europe. Previous studies have suggested that range contraction during previous phases of climate change was characterized by population extinction, rather than migration [6,53]. Although the future model indicates a range expansion at the northern edge, it also suggests extensive loss of suitable habitat in southeastern Europe. Given that this area represents the centre of genetic diversity for the species, extinction of these populations would lead to massive loss of genetic diversity since more northerly populations are genetically depauperate relative to populations in the southeast. A northern expansion of the species' range would not counter this, because the leading edge colonization would be from these low-diversity northern populations. Northern populations of $O$. secunda, however, tended to be more genetically diverse than those of $M$. hypopitys. 
Consequently, the loss of southern and central European $O$. secunda populations indicated by the species distribution model would not have the same overall effect on total intraspecific genetic diversity across the continent. Nevertheless, although the populations from the species' centres of diversity in the French and Austrian Alps would still lie within the future modelled climate envelope, this would most likely be as a result of altitudinal migration, since the mountain ranges of southern and eastern Europe represent the only climatically suitable areas in the region. Whilst altitudinal migration offers some short-term potential for countering the effects of climate change [54-57], its scope is ultimately limited [58]. The situation in Europe is somewhat different from that in North America, where the occurrence of northern refugia for both species means that a lower proportion of the total genetic diversity in the continent is concentrated in southern populations [[34], Beatty \& Provan, unpublished results] and thus the impact of loss of rear-edge populations might not be as extreme. It should also be borne in mind that models of future (and, indeed, past) climate are not guaranteed to be $100 \%$ accurate, and that many other factors such as changes in species tolerances through adaptation and species-species interactions will also determine species current and future ranges. Nevertheless, at least in Europe, the adverse encroachment of human activity on the boreal and temperate woodlands that form the natural habitat for these species, coupled with the fact that climate is changing faster now than at any time in the past, means that the impacts on the gene pools and subsequent adaptive potential of these, and possibly many other species, are likely to be potentially serious.

\section{Conclusions}

Both Orthilia secunda and Monotropa hypopitys appear to have persisted through the LGM in Europe in southern refugia. The boreal $O$. secunda, however, has retained a larger proportion of its genetic diversity in more northerly populations outside these refugial areas than the temperate $M$. hypopitys. Given that future species distribution modelling suggests northern range shifts and loss of suitable habitat in the southern parts of the species' current distributions, extinction of genetically diverse rear edge populations could have a significant effect in the rangewide intraspecific diversity of both species, but particularly in M. hypopitys.

\section{Acknowledgements}

We are extremely grateful to everybody who provided samples for this project (listed in Tables 1a and 1b). Jan Wieringa (Nationaal Herbarium Nederland) provided valuable herbarium specimens. Gemma Beatty's PhD research is funded by the Department of Agriculture and Rural Development, Northern Ireland.

\section{Authors' contributions}

Both authors conceived and designed the study. GEB carried out the laboratory work. Both authors analysed the data and wrote the manuscript.

Received: 4 September 2010 Accepted: 27 January 2011

Published: 27 January 2011

\section{References}

1. Emiliani C: Quaternary paleotemperatures and the duration of high temperature intervals. Science 1972, 178:398-401.

2. Winograd IJ, Szabo BJ, Coplen TB, Riggs AC: A 250 000-year climatic record from Great Basin vein calcite: implications for Milankovitch theory. Science 1988, 242:1275-1280.

3. Jansen E, Sjoholm J: Reconstruction of glaciations over the past $6 \mathrm{Myr}$ from ice-borne deposits in the Norwegian Sea. Nature 1991, 349:600-603.

4. FAUNMAP Working Group: Spatial response of mammals to Late Quaternary environmental fluctuations. Science 1996, 272:1601-1606.

5. Hewitt GM: Ice ages: their impact on species distributions and evolution. In Evolution on Planet Earth. Edited by: Rothschild L, Lister AM. Academic Press, London; 339-361.

6. Bennett KD, Tzedakis PC, Willis KJ: Quaternary refugia of north European trees. J Biogeogr 1991, 18:103-115.

7. Bennett KD, Provan J: What do we mean by 'refugia'? Quaternary Sci Rev 2008, 27:2449-2455.

8. Comes HP, Kadereit JW: The effects of Quaternary climatic changes on plant distribution and evolution. Trends Ecol Evol 1998, 8:432-438.

9. Hu FS, Hampe A, Petit RJ: Paleoecology meets genetics: deciphering past vegetational dynamics. Front Ecol Environ 2009, 7:371-379.

10. Harrison SP, Sanchez Goñi MF: Global patterns of vegetation response to millennial-scale variability and rapid climate change during the last glacial period. Quaternary Sci Rev 2010.

11. Walther GR, Post E, Convey P, Menzel A, Parmesan C, Beebee TJC, Fromentin JM, Hoegh-Gulberg O, Bairlein F: Ecological responses to recent climate change. Nature 2002, 416:389-395.

12. Parmesan $\mathrm{C}$, Yohe $\mathrm{G}$ : A globally coherent fingerprint of climate change impacts across natural systems. Nature 2003, 421:37-42.

13. Root TL, Price JT, Hall KR, Schneider SH, Rosenzweig C, Pounds JA: Fingerprints of global warming on wild animals and plants. Nature 2003, 421:57-60.

14. Parmesan C: Ecological and evolutionary response to recent climate change. Ann Rev Ecol Evol Syst 2006, 37:637-669.

15. Thomas CD, Cameron A, Green RE, Bakkenes M, Beaumont LJ, Collingham YC, Erasmus BFN, de Siqueira MF, Grainger A, Hannah L, Hughes L, Huntley B, van Jaarsveld AS, Midgley GF, Miles L, OrtegaHuerta MA, Peterson AT, Phillips OL, Williams SE: Extinction risk from climate change. Nature 2004, 427:145-148.

16. Foden W, Midgely GF, Hughes GO, Bond WJ, Thuiller W, Hoffman MT, Kaleme P, Underhill LG, Rebelo AG, Hannah L: A changing climate is eroding the geographical range of the Namib Desert tree Aloe through population declines and dispersal lags. Diversity Distrib 2007, 13:645-653.

17. Gaston KJ: The Structure and Dynamics of Geographic Ranges Oxford: Oxford University Press; 2003.

18. Vucetich JA, Waite TA: Spatial patterns of demography and genetic processes across the species' range: null hypotheses for landscape conservation genetics. Conserv Genet 2003, 4:639-645.

19. Eckert CG, Samis KE, Lougheed SC: Genetic variation across species' geographical ranges: the central-marginal hypothesis and beyond. $\mathrm{Mol}$ Ecol 2008, 17:1170-1188.

20. Hampe A, Petit RJ: Conserving biodiversity under climate change: the rear edge matters. Ecol Lett 2005, 8:461-467.

21. Hewitt GM: The genetic legacy of the Quaternary ice ages. Nature 2000, 405:907-913.

22. Taberlet $P$, Fumagalli $L$, Wust-Saucy AG, Cossons JF: Comparative phylogeography and post-glacial recolonization routes in Europe. $\mathrm{Mol}$ Ecol 1998, 7:453-464.

23. Hewitt GM: Post-glacial recolonisation of European biota. Biol J Linnean Soc 1999, 68:87-112.

24. Petit RJ, Auinagalde I, de Beaulieu J-L, Bittkau C, Brewer S, Cheddadi R, Ennos R, Fineschi S, Grivet D, Lascoux M, Mohanty A, Muller-Starck GM, Demesure-Musch B, Palme A, Martin JP, Rendell S, Vendramin GG: Glacial 
refugia: hotspots but not melting pots of genetic diversity. Science 2003, 300:1563-1565.

25. Stewart JR, Lister AM: Cryptic northern refugia and the origins of the modern biota. Trends Ecol Evol 2001, 16:608-613.

26. Provan J, Bennett KD: Phylogeographic insights into cryptic glacial refugia. Trends Ecol Evol 2008, 23:564-571.

27. Stewart JR, Lister AM, Barnes I, Dalén L: Refugia revisited: individualistic responses of species in space and time. Proc Roy Soc B 2010, 277:661-671.

28. Frankham R: Genetics and extinction. Biol Conserv 2005, 126:131-140.

29. Phillips SJ, Anderson RP, Schapire RE: Maximum entropy modeling of species geographic distributions. Ecol Model 2006, 190:231-259.

30. Hijmans RJ, Cameron SE, Parra JL, Jones PG, Jarvis A: Very high resolution interpolated climate surfaces for global land areas. J Climatol 2005, 25:1965-1978.

31. Booth GD, Niccolucci MJ, Schuster EG: Identifying proxy sets in multiple linear regression: an aid to better coefficient interpretation Research paper INT-470. United States Department of Agriculture Forest Service, Ogden, UT; 1994.

32. Govindasamy B, Duffy PB, Coquard J: High resolution simulations of global climate, part 2: effects of increased greenhouse gases. Clim Dynamics 2003, 21:391-404.

33. Cantor SB, Sun CC, Tortolero-Luna G, Richards-Kortum R, Follen M: A comparison of $C / B$ ratios from studies using receiver operating characteristic curve analysis. J Clin Epidem 1999, 52:885-892.

34. Beatty GE, Provan J: Refugial persistence and postglacial recolonization of North America by the cold-tolerant herbaceous plant Orthilia secunda. Mol Ecol 2010, 19:5009-5021.

35. Beatty GE, McEvoy PM, Sweeney O, Provan J: Range-edge effects promote clonal growth in peripheral populations of the one-sided wintergreen (Orthilia secunda). Diversity Distrib 2008, 14:546-555.

36. Bidartondo MI, Bruns TD: Extreme specificity in epiparasitic Monotropoideae (Ericacea): widespread phylogenetic and geographic structure. Mol Ecol 2001, 10:2285-2295.

37. Klooster MR, Hoenle AW, Culley TM: Characterization of microsatellite loci in the myco-heterotrophic plant Monotropa hypopitys (Ericaceae) and amplification in related taxa. Mol Ecol Resources 2009, 9:219-221.

38. Provan J, Wilson PJ: Development of microsatellites for the peat moss Sphagnum capillifolium using ISSR cloning. Mol Ecol Notes 2007, 7:254-256.

39. Beatty GE, Provan J: High clonal diversity in threatened peripheral populations of the yellow bird's nest (Hypopitys monotropa; syn. Monotropa hypopitys). Annals Bot 2011.

40. Hall TA: BIOEDIT: a user-friendly biological sequence alignment editor and analysis program for Windows 95/98/NT. Nucleic Acids Symp Ser 1999, 41:95-98.

41. Provan J, Powell W, Hollingsworth PM: Chloroplast microsatellites: new tools for studies in plant ecology and systematics. Trends Ecol Evol 2001, 16:142-147.

42. Clement M, Posada D, Crandall KA: TCS: a computer program to estimate gene genealogies. Mol Ecol 2000, 9:1657-1659.

43. Pfenninger M, Posada D: Phylogeographic history of the land snail Candidula unifasciata (Helicellinae, Stylommatophora): fragmentation, corridor migration and secondary contact. Evolution 2002, 56:1776-1788.

44. Goudet J: FSTAT, version 2.9.3, A program to estimate and test gene diversities and fixation indices. [http://www2.unil.ch/popgen/softwares/ fstat.htm].

45. Excoffier L, Laval LG, Schneider S: ARLEQUIN, Version 3.0: An integrated software package for population genetic data analysis. Evol Bioinf Online 2005, 1:47-50.

46. Pritchard JK, Stephens M, Donnelly P: Inference of population structure using multilocus genotype data. Genetics 2000, 155:945-959.

47. Evanno G, Regnaud $\mathrm{S}$, Goudet J: Detecting the number of clusters of individuals using the software STRUCTURE: a simulation study. Mol Ecol 2005, 14:2611-2620.

48. Bermingham E, Moritz C: Comparative phylogeography: concepts and applications. Mol Ecol 1998, 7:367-369.

49. Schaal BA, Hayworth DA, Olsen KM, Rauscher JT, Smith WA Phylogeographic studies in plants: problems and prospects. Mol Ecol 1998, 7:465-474

50. Thuiller W, Lavorel S, Araújo MB, Sykes MT, Prentice IC: Climate change threats to plant diversity in Europe. Proc Natl Acad Sci USA 2005, 102:8245-8250.
51. Hijmans RJ, Graham CH: The ability of climate envelope models to predict the effect of climate change on species distributions. Global Change Biol 2006, 12:2272-2281.

52. McKenney DW, Pedlar JH, Lawrence $\mathrm{K}$, Campbell $\mathrm{K}$, Hutchinson MF: Potential impacts of climate change on the distribution of North American trees. Bioscience 2007, 57:939-948.

53. Dalen L, Nystrom V, Valdiosera C, Germonpre M, Sablin M, Turner E, Angerbjorn A, Arsuaga JL, Gotherstrom A: Ancient DNA reveals lack of postglacial habitat tracking in the Arctic fox. Proc Natl Acad Sci USA 2007, 104:6726-6729.

54. Hill JK, Thomas CD, Fox R, Telfer MG, Willis SG, Asher J, Huntley B: Responses of butterflies to twentieth century climate warming: implications for future ranges. Proc Roy Soc B 2002, 269:2163-2171.

55. Daniels LD, Veblen TT: Spatiotemporal influences of climate on altitudinal treeline in northern Patagonia. Ecology 2004, 85:1284-1296.

56. Parolo G, Rossi G: Upward migration of vascular plants following a climate warming trend in the Alps. Basic Appl Ecol 2008, 9:100-107.

57. Lenoir J, Gegout JC, Marquet PA, de Ruffray P, Brisse H: A significant upward shift in plant species optimum elevation during the $20^{\text {th }}$ century. Science 2008, 320:1768-1771.

58. Jump AS, Matyas C, Peñuelas J: The altitude-for-latitude disparity in the range retractions of woody species. Treends Ecol Evol 2009, 24:694-701.

doi:10.1186/1471-2148-11-29

Cite this article as: Beatty and Provan: Comparative phylogeography of two related plant species with overlapping ranges in Europe, and the potential effects of climate change on their intraspecific genetic diversity. BMC Evolutionary Biology 2011 11:29.

\section{Submit your next manuscript to BioMed Central and take full advantage of:}

- Convenient online submission

- Thorough peer review

- No space constraints or color figure charges

- Immediate publication on acceptance

- Inclusion in PubMed, CAS, Scopus and Google Scholar

- Research which is freely available for redistribution

Submit your manuscript at www.biomedcentral.com/submit
C Biomed Central 